Historic, Archive Document

Do not assume content reflects current scientific knowledge, policies, or practices. 



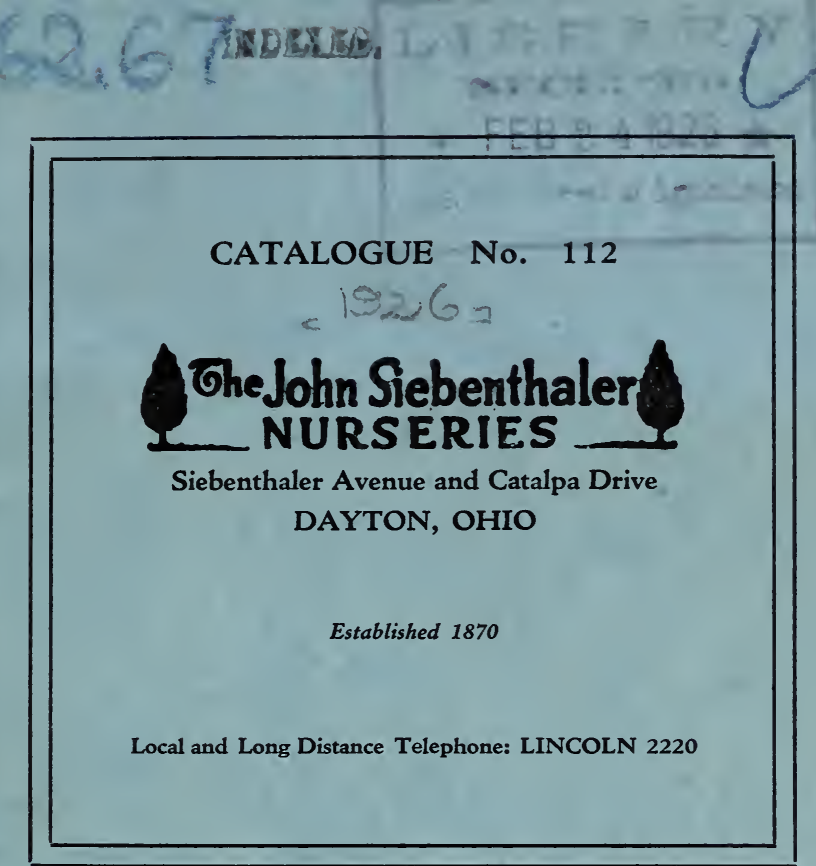




\section{CATALOGUE No. 112}

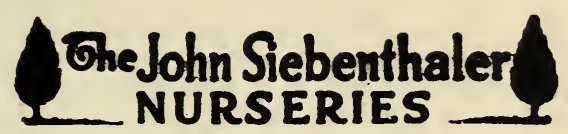

Siebenthaler Avenue and Catalpa Drive DAYTON, OHIO

Established 1870

Local and Long Distance Telephone LINCOLN 2220 
DIRECTIONS FOR ORDERING: Write plainly and give explicit directions as to address and mode of shipment. Shipments will be forwarded exactly as directed, but in the absence of specific instructions, we will use our best judgment and forward by the shortest and safest route. We recommend that all herbaceous plants be shipped by express. All shipments travel at the risk and cost of the purchaser.

PRICES: Prices in this list cancel all previous lists and quotations and are subject to change without notice. The bulky pieces, for which cost of packing will be extra. These prices are F. O. B. our shipping station or for local delivery they are F. O. B. customer's place if within 10 miles of our nurseries on all orders of Ten Dollars or more. Arrangements can be made for distance deliveries by motor truck, if desired.

QUANTITY: At the prices named herein 5 plants will be furnished at the 10 rate; 6 at the 12 rate and 25 at the 100 rate.

TERMS: Cash with order, except to persons who satisfy us as to their responsibility, when accounts will be due in 30 days from date of invoice.

INSPECTION: Our plants are regularly inspected and a certificate of inspection will be attached to each shipment.

GUARANTEE: All plants are warranted true to name, full count, up to size specified and in good, healthy condition when shipped. Any plant proving otherwise will be replaced or the original amount paid will be refunded. Our stock is of the highest grade, thrifty and well grown, insuring its success if properly cared for after transplanting. As we have no control over its usage after it leaves our hands, properly packed and in good condition, we can not guarantee it to grow; however, any just complaint will receive our utmost consideration. All complaints of error on our part, except that of untrueness of name, must be made within five days after recript of goods PLANTS ARE LIVING ORGANISMS and THEIR SUCCESS DEPENDS UPON THE CARE YOU GIVE THEM. TREAT THEM WELL and do not hesitate to confer with us, at any time, regarding the care that should be given them. WE WANT THEM TO GROW AND THRIVE FOR YOU.

LANDSCAPE SERVICE: We maintain a thoroughly trained landscape organization, equipped in every respect from the drawing of plans to their execution.

PLANTING: At a slight additional charge per plant we are equipped to plant upon your grounds, within a radius of ten miles from the center of Dayton, any of the stock named in this list.

LOCATION: Our nurseries are located three and onehalf miles northwest of the center of Dayton on the corner of Siebenthaler Avenue and Catalpa Drive.

To reach the nurseries by Trolley: Take north-bound White Line Car to the loop, walk north to Siebenthaler Avenue, then one-third mile west; or take north-bound Dayton Street Railway Car to loop [Catalpa Drive] and walk one mile due north.

To drive to the nurseries: Out North Main Street to Siebenthaler Avenue and one-third mile west; or north on Salem Avenue to Catalpa Drive and one mile north. 


\section{EVERGREEN TREES}

Our Evergreens have been transplanted frequently and many have been sheared, insuring a mass of fibrous roots and well-shaped top. Prices include balling and burlaping.

\section{CHAMAEGYPARIS [Retinospora]}

Each Per 10 Per 100

- pisifera

- - aurea

4 to $5 \mathrm{ft}$

- - filifera

3 to $4 \mathrm{ft}$

- plumosa

18 to 24 in

2 to $3 \mathrm{ft}$.

3 to $4 \mathrm{ft}$

4 to $5 \mathrm{ft}$

\section{- - aurea}

18 to 24 in

2 to $3 \mathrm{ft}$

3 to $4 \mathrm{ft}$.

4 to $5 \mathrm{ft}$

\section{- - squarrosa}

18 to 24 in

2 to $3 \mathrm{ft}$

3 to $4 \mathrm{ft}$

4 to $5 \mathrm{ft}$.
Sawara Retinospora

8.00

Golden Sawara Retinospora 8.00

6.00

Thread Retinospora

Plume Retinospora

2. 25

$3.00 \quad 25.00$

$4.00 \quad 35.00$

$5.50 \quad 50.00$

Goldenplume Retinospora

2.50

$3.00 \quad 25.00$

$4.50 \quad 40.00$

$6.00 \quad 55.00$

Moss Retinospora

3.00

4.00

6.00

8.00

JUNIPERUS chinensis pfitzeriana

15 to 18 in.

18 to 24 in.

2 to $21 / 2 \mathrm{ft}$

$21 / 2$ to $3 \mathrm{ft}$.

- horizontalis

15 to 18 in

18 to 24 in

Pfitzer Juniper

$2.75 \quad 25.00$

$4.00 \quad 35.00$

$5.50 \quad 50.00$

$7.00 \quad 65.00$

alpinus

15 to 18 in

Creeping Juniper

$2.25 \quad 20.00$

$3.00 \quad 27.50$

18 to 24 in

2 to $3 \mathrm{ft}$

Alpine Creeping Juniper

2.25

3.00

3.50

- glauca

15 to 18 in

Blue Creeping Juniper

$2.25 \quad 20.00$

$3.00 \quad 27.50$

2 to $3 \mathrm{ft}$..

$3.50 \quad 32.50$

\section{- sabina}

12 to 15 in

Savin Juniper

15 to 18 in

18 to 24 in

$2.00 \quad 18.50$

$2.50 \quad 22.50 \quad 200.00$

$3.25 \quad 30.00$

Tamarix Savin Juniper

12 to 15 in

$2.50 \quad 22.50$

$3.00 \quad 27.50$

$3.50 \quad 32.50$

18 to 24 in

Redcedar

- virginiana

6 to $7 \mathrm{ft}$.

8.00

Silver Redcedar

2 to $3 \mathrm{ft}$

3 to $4 \mathrm{ft}$

8.00

10.00 


\section{LARIX europaea}

6 to $8 \mathrm{ft}$

\section{PICEA canadensis}

12 to 15 in

30 to 36 in

- excelsa

18 to 24 in

2 to $3 \mathrm{ft}$

3 to $4 \mathrm{ft}$

4 to $5 \mathrm{ft}$

5 to $6 \mathrm{ft}$

- pungens

3 to $4 \mathrm{ft}$

- - kosteri

2 to $21 / 2 \mathrm{ft}$.

$21 / 2$ to $3 \mathrm{ft}$.

3 to $31 / 2 \mathrm{ft}$

$31 / 2$ to $4 \mathrm{ft}$.

4 to $41 / 2 \mathrm{ft}$.

$41 / 2$ to $5 \mathrm{ft}$.

PINUS nigra [austriaca]

3 to $4 \mathrm{ft}$.

- montana mughus

12 to 15 in.

15 to 18 in

- sylvestris

2 to $3 \mathrm{ft}$

\section{PSEUDOTSUGA douglasi}

2 to $3 \mathrm{ft}$.

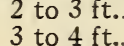

\section{RETINOSPORA [SEe CHAMAECYPARIS]}

TAXUS cuspidata

15 to 18 in.

\section{- - brevifolia}

15 to 18 in.

18 to 24 in

THUJA occidentalis

15 to 18 in

18 to 24 in

2 to $3 \mathrm{ft}$

3 to $4 \mathrm{ft}$

4 to $5 \mathrm{ft}$

\section{- compacta}

12 to 15 in

15 to 18 in.

18 to 24 in

2 to $3 \mathrm{ft}$...

\section{- ellwangeriana}

12 to 15 in

15 to 18 in.

18 to 24 in

3 to $4 \mathrm{ft}$.

\section{- - ericoides}

12 to 15 in

15 to 18 in

18 to 24 in

8.00

3.50

4.00
Each Per 10 Per 100

European Larch

6.00

White Spruce

2.00

3.50

Norway Spruce

$\begin{array}{lll}2.00 & 15.00 & 125.00\end{array}$

$\begin{array}{lll}3.00 & 25.00 & 200.00\end{array}$

$\begin{array}{lll}4.00 & 35.00 & 300.00\end{array}$

$\begin{array}{lll}5.00 & 45.00 & 400.00\end{array}$

$\begin{array}{lll}6.50 & 57.50 \quad 500.00\end{array}$

Colorado Spruce

8.00

17.00

20.00

22.50

25.00

27.50

35.00

6.00

3.50

4.50

2.50

Austrian Pine

Mugho Pine

Scotch Pine

Douglas Fir

4.00

5.00

Koster's Blue Spruce

Japanese Yew

$6.00 \quad 55.00$

Dwarf Japanese Yero

$6.00 \quad 55.00$

American Arborvitae

$\begin{array}{lll}1.50 & 12.50 & 100.00\end{array}$

$\begin{array}{lll}2.00 & 17.50 & 150.00\end{array}$

$\begin{array}{lll}3.25 & 30.00 & 250.00\end{array}$

$\begin{array}{lll}5.50 & 50.00 & 450.00\end{array}$

$\begin{array}{lll}6.50 & 60.00 \quad 500.00\end{array}$

Parsons Arborsitae

$2.25 \quad 20.00$

$2.50 \quad 22.50$

$3.00 \quad 27.50$

Ellwangers Arboroitae

$\begin{array}{lll}1.50 & 12.50\end{array}$

$2.00 \quad 17.50$

$2.50 \quad 22.50$

Heath Arborvitae

$1.50 \quad 12.50$

$2.00 \quad 17.50$

$2.50 \quad 22.50$ 
THUJA occidentalis-coninued

- globosa

15 to 18 in

18 to 24 in.

2 to $3 \mathrm{ft}$.

- hoveyi

12 to 15 in

15 to 18 in.

18 to 24 in.

\section{- lutea}

15 to 18 in.

18 to 24 in.

2 to $3 \mathrm{ft}$.

3 to $4 \mathrm{ft}$.

\section{- pyramidalis}

15 to 18 in.

18 to 24 in.

2 to $3 \mathrm{ft}$.

3 to $4 \mathrm{ft}$.

4 to $5 \mathrm{ft}$.

\section{- Tom Thumb}

12 to 15 in

15 to $18 \mathrm{in}$

18 to 24 in.

\section{- vervaeneana}

12 to 15 in.

15 to $18 \mathrm{in}$.

2 to $3 \mathrm{ft}$.

3 to $4 \mathrm{ft}$

\section{- wareana}

12 to 15 in

15 to 18 in

18 to 24 in

2 to $3 \mathrm{ft}$

\section{- - lutea}

12 to 15 in

15 to 18 in

18 to 24 in

\section{- woodwardi}

12 to 15 in

15 to 18 in

- orientalis

12 to 15 in

18 to 24 in

2 to $21 / 2 \mathrm{ft}$.

$21 / 2$ to $3 \mathrm{ft}$.

3 to $4 \mathrm{ft}$..

4 to $5 \mathrm{ft}$

5 to $6 \mathrm{ft}$
Each Per 10 Per 100

Globe Arborvitae

$2.75 \quad 25.00$

$3.00 \quad 27.50$

$4.00 \quad 35.00$

Hovey Arborvitae

$\begin{array}{ll}2.25 & 20.00\end{array}$

$2.50 \quad 22.50$

$3.00 \quad 27.50$

Peabody Arborvitae

$2.50 \quad 22.50$

$3.00 \quad 27.50$

$3.50 \quad 32.50$

5.00

Pyramidal Arborvitae

$\begin{array}{lll}2.00 & 15.00 & 125.00\end{array}$

$\begin{array}{lll}2.75 & 25.00 & 225.00\end{array}$

$3.75 \quad 35.00 \quad 325.00$

$\begin{array}{lll}6.00 & 55.00 \quad 500.00\end{array}$

$8.00 \quad 75.00$

Tom Thumb Arborvitae

$1.50 \quad 12.50$

$2.00 \quad 17.50$

$2.50 \quad 22.50$

Vervaene Arborvitae 2.50

3.50

4.50

6.00

40.00

Wares Arborvitae

$2.25 \quad 20.00$

$\begin{array}{lll}2.75 & 25.00 & 225.00\end{array}$

$\begin{array}{lll}3.50 & 32.50 & 300.00\end{array}$

$4.50 \quad 40.00$

Wares Golden Arborvitae

$2.25 \quad 20.00$

$2.75 \quad 25.00$

$3.50 \quad 32.50$

Woodward Arborvitae

$\begin{array}{lll}2.50 & 20.00 & 175.00\end{array}$

$3.00 \quad 25.00 \quad 225.00$

Oriental Arborvitae

$1.75 \quad 15.00$

$2.00 \quad 17.50$

$2.50 \quad 20.00 \quad 175.00$

$3.00 \quad 25.00 \quad 225.00$

$5.00 \quad 45.00$

6.00

7.50

Berckmans Golden Arboroitae

12 to 15 in.

$4.00 \quad 35.00$

15 to 18 in.

$6.00 \quad 50.00$

18 to 24 in

8.00

70.00

24 to 30 in

15.00

20.00

30.00

36 to 42 in.

45.00

42 to 48 in

Compact Oriental Arborvitae

12 to 15 in. 2.25

15 to 18 in.

18 to 24 in

2.75

3.25

4.00 
TSUGA canadensis

2 to $3 \mathrm{ft}$..

Each Per 10 Per 100

3 to $4 \mathrm{ft}$.

4.00

Canada Hemlock

4 to $5 \mathrm{ft}$

6.00

8.00

- caroliniana

12 to 15 in

3.50

2 to $3 \mathrm{ft}$

6.00

3 to $4 \mathrm{ft}$.

8.00

Carolina Hemlock

\section{DECIDUOUS SHADE AND ORNAMENTAL TREES}

Caliper measurements are taken six inches above ground.

Each Per 10 Per 100

\section{ACER dasycarpum}

4 to $6 \mathrm{ft}$.

6 to $8 \mathrm{ft}$

Silver Maple

8 to $10 \mathrm{ft}$.

$\begin{array}{lll}.85 & 7.50 & 60.00\end{array}$

$\begin{array}{lll}1.10 & 10.00 & 85.00\end{array}$

10 to $12 \mathrm{ft}$

$\begin{array}{lll}1.50 & 12.50 & 100.00\end{array}$

$11 / 11 / 2$ in in diam

$\begin{array}{lll}2.00 & 17.50 & 150.00\end{array}$

$\begin{array}{lll}2.50 & 22.50 & 175.00\end{array}$

$\begin{array}{lll}3.00 & 25.00 & 200.00\end{array}$

$11 / 2$ to 2 in. in diameter.

$\begin{array}{lll}5.00 & 42.50 \quad 350.00\end{array}$

- - wieri

8 to $10 \mathrm{ft}$

2.50

Wier Cutleaf Maple

- negundo

1 to $11 / 2$ in in diameter.

$11 / 2$ to $21 / 2$ in. in diameter.

2.00

3.00

- platanoides

$1 \frac{1}{2}$ to 2 in. in diameter.

2 to $2 \frac{1}{2}$ in. in diameter

$21 / 2$ to 3 in. in diameter.

3 to $31 / 2$ in. in diameter

$31 / 2$ to 4 in. in diameter.

5.00

8.00

12.00

15.00

20.00

- platanoides [Special XX]

$11 / 2$ to $13 / 4$ in. in diameter

Speicmen Norway Maple

$13 / 4$ to 2 in. in diameter

8.00

2 to $21 / 2$ in. in diameter............ 15.00

$21 / 2$ to 3 in. in diameter............ 20.00

- - schwedleri

Schwedler Purpleleaf Maple

$11 / 4$ to $11 / 2$ in. in diameter

$1 \frac{1}{2}$ to $11 / 4$ in. in diameter.

8.00

10.00

- saccharum

8 to $10 \mathrm{ft}$.

$11 / 4$ to $11 / 2$ in. in diameter

$1 \frac{1}{2}$ to $13 / 4$ in. in diameter.

AESCULUS carnea

8 to $10 \mathrm{ft}$.

$\begin{array}{ll} & \text { Sugar Maple } \\ 2.50 & 22.50 \\ 3.50 & 30.00 \\ 4.00 & 35.00\end{array}$

Red Flowering Horsechestnut

- hippocastanum

6 to $8 \mathrm{ft}$.

8 to $10 \mathrm{ft}$.

Horsechestnut

2 to $21 / 2$ in. in diameter

$21 / 2$ to 3 in. in diameter

3 to $31 / 2$ in. in diameter.

2.50

2.50

3.50

5.00

8.00

12.00

$31 / 2$ to 4 in. in diameter.

15.00

4 to 5 in. in diameter.

20.00

5 to 6 in. in diameter.

30.00

BETULA pendula laciniata

4 to $5 \mathrm{ft}$.

5 to $6 \mathrm{ft}$

Cutleaf Weeping Birch

4.50

5.00

6 to $8 \mathrm{ft}$.

6.00

30.00 
CATALPA bungei

Two year old heads.

Three year old heads

\section{- speciosa}

6 to $8 \mathrm{ft}$..

8 to $10 \mathrm{ft}$.

10 to $12 \mathrm{ft}$.

\section{CEDRELA sinensis}

3 to $4 \mathrm{ft}$.

\section{CERCIS canadensis}

2 to $3 \mathrm{ft}$.

3 to $4 \mathrm{ft}$.

\section{CORNUS florida}

2 to $3 \mathrm{ft}$.

- rubra

2 to $3 \mathrm{ft}$.

\section{CRATAEGUS crusgalli}

5 to $6 \mathrm{ft}$.

6 to $8 \mathrm{ft}$.

\section{- mollis}

5 to $6 \mathrm{ft}$.

6 to $8 \mathrm{ft}$.

- oxycantha pauli

3 to $4 \mathrm{ft}$.

- punctata

5 to $6 \mathrm{ft}$.

- Assorted Species

8 to $10 \mathrm{ft}$.

FAGUS sylvatica purpurea

8 to $10 \mathrm{ft}$.

\section{FRAXINUS americana}

6 to $8 \mathrm{ft}$.....

8 to $10 \mathrm{ft}$

\section{GINKO biloba}

$11 / 4$ to $11 / 2$ in. in diameter

$11 / 2$ to 2 in. in diameter.

\section{LIRIODENDRON tulipifera}

$11 / 2$ to 2 in. in diameter.

2 to $2 \frac{1}{2}$ in. in diameter.

MALUS angustifolia rosea plena

2 to $3 \mathrm{ft}$

3 to $4 \mathrm{ft}$

\section{- arnoldiana}

3 to $4 \mathrm{ft}$.

- atrosanguinea

3 to $4 \mathrm{ft}$.

- coronaria

3 to $4 \mathrm{ft}$.

4 to $5 \mathrm{ft}$.

- thomsi

2 to $3 \mathrm{ft}$

3 to $4 \mathrm{ft}$.

4 to $5 \mathrm{ft}$.
Each Per 10 Per 100

Umbrella Catalpa

$\begin{array}{lll}2.50 & 20.00 & 150.00\end{array}$

$\begin{array}{lll}3.50 & 30.00 & 250.00\end{array}$

Western Catalpa

$\begin{array}{lll}.75 & 6.50 & 50.00\end{array}$

$\begin{array}{lll}1.25 & 10.00 & 75.00\end{array}$

$2.00 \quad 17.50$

Chinese Cedrela

$\begin{array}{ll}1.50 & 10.00\end{array}$

American Redbud

$\begin{array}{ll}1.50 & 12.50\end{array}$

$2.50 \quad 20.00$

White Flowering Dogwood $1.50 \quad 12.50$

Pink Flowering Dogwood $3.50 \quad 32.50$

2.50 Cockspur Thorn

3.50

2.50

3.50

Paul English Hawthorn 2.50

3.50 Dotted Hawthorn

5.00 Flowering Thorns

Purple Beech

12.00

White Ash

$1.50 \quad 12.50$

$2.00 \quad 17.50$

3. Maidenhair Tree

4.00

$3.50 \quad 32.50$ Tuliptree

$5.00 \quad 45.00$

Pink Flowering Southern Crab

$1.50 \quad 12.50$

$2.00 \quad 17.50$

Arnold Crab

2.00

Carmine Crab

$2.00 \quad 17.50$

Wild Sweet Crab

$2.00 \quad 17.50$

$2.75 \quad 25.00$

Sweet Scented Wild Crab

1.50

2.00

2.75 
MALUS-continued

- floribunda

3 to $4 \mathrm{ft}$.

4 to $5 \mathrm{ft}$

- halliana parkmani

2 to $3 \mathrm{ft}$.

3 to $4 \mathrm{ft}$.

- ioensis plena

2 to $3 \mathrm{ft}$.

3 to $4 \mathrm{ft}$.

- niedzwetskyana

2 to $3 \mathrm{ft}$.

3 to $4 \mathrm{ft}$.

- prunifolia rinki

3 to $4 \mathrm{ft}$.

- scheideckeri

2 to $3 \mathrm{ft}$.

3 to $4 \mathrm{ft}$

- sieboldi

3 to $4 \mathrm{ft}$.

- spectabilis riversi flore plena

3 to $4 \mathrm{ft}$.

- sublobata

3 to $4 \mathrm{ft}$.

MORUS alba pendula

Two year old heads

PLATANUS orientalis

2 to 3 in. in diameter

3 to 4 in. in diameter.

POPULUS bolleana

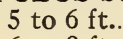

6 to $8 \mathrm{ft}$.

- nigra italica

6 to $8 \mathrm{ft}$.

8 to $10 \mathrm{ft}$.

10 to $12 \mathrm{ft}$

12 to $15 \mathrm{ft}$.

15 to $20 \mathrm{ft}$.
2.00

2.00

Each Per 10 Per 100

Japanese Flowering Crab

$2.00 \quad 17.50$

$2.75 \quad 25.00$

1.50

2.00

Parkman Crab

Bechtel Crab

$1.50 \quad 12.50$

$2.00 \quad 17.50^{\circ}$

Redvein Crab

Chinese Apple

Scheidecker Crab

$\begin{array}{ll}1.50 & \\ 2.00 & 17.50\end{array}$

2.00

Toringo Crab

Chinese Flowering Crab $2.00 \quad 17.50$

2.00

Yellow Autumn Crab

Tea's Weeping Mulberry 4.00

European Planetree 20.00

Bolleana Poplar

$\begin{array}{lll}1.50 & 12.50 & 100.00\end{array}$

$2.00 \quad 15.00 \quad 125.00$

Lombardy Poplar

$\begin{array}{lll}1.50 & 12.50 & 100.00\end{array}$

$2.00 \quad 15.00 \quad 125.00$

$\begin{array}{lll}2.75 & 22.50 & 175.00\end{array}$

$\begin{array}{lll}3.50 & 30.00 & 250.00\end{array}$

$\begin{array}{lll}6.00 & 50.00 \quad 450.00\end{array}$

PRUNUS subhirtella japonica flore plena

4 to $6 \mathrm{ft}$.

- triloba

3 to $4 \mathrm{ft}$.

QUERCUS palustris

6 to $8 \mathrm{ft}$.

8 to $10 \mathrm{ft}$.

10 to $12 \mathrm{ft}$

- phellos

4 to $6 \mathrm{ft}$.

6 to $8 \mathrm{ft}$.

8 to $10 \mathrm{ft}$.

- rubra

6 to $8 \mathrm{ft}$

8 to $10 \mathrm{ft}$.

SALIX babylonica

4 to $5 \mathrm{ft}$.
Dbl. Flowering Japanese Cherry

$3.00 \quad 25.00$

2.00 Flowering Plum

\begin{tabular}{ll} 
& \multicolumn{1}{c}{ Pin Oak } \\
2.50 & 22.50 \\
3.00 & 27.50 \\
5.00 & 45.00 \\
& \multicolumn{1}{c}{ Willow Oak } \\
4.00 & 37.50 \\
5.00 & 45.00 \\
6.00 & 55.00
\end{tabular}

$2.50 \quad 22.50$ Red Oak

$3.50 \quad 32.50$

Babylon Weeping Willow $1.50 \quad 10.00$ 
SALIX - continued

- blanda

4 to $5 \mathrm{ft}$

- pentandra

4 to $5 \mathrm{ft}$

- elegantissima

4 to $5 \mathrm{ft}$

- vitellina

4 to $5 \mathrm{ft}$

6 to $8 \mathrm{ft}$.

\section{SORBUS aucuparia}

4 to $5 \mathrm{ft}$

TILIA vulgaris

8 to $10 \mathrm{ft}$.

$1 \frac{1}{2}$ to 2 in. in diameter.

2 to $21 / 2$ in. in diameter.

$2 \frac{1}{2}$ to 3 in. in diameter.

\section{ULMUS americana}

$1 \frac{1}{4}$ to $1 \frac{1}{2}$ in. in diameter

$11 / 2$ to 2 in. in diameter.

2 to $2 \frac{1}{2}$ in in diameter.

$21 / 2$ to 3 in. in diameter.

3 to $3 \frac{1}{2}$ in. in diameter.

- americana Special

2 to $2 \frac{1}{2}$ in. in diameter.

$21 / 2$ to 3 in. in diameter.

3 to 4 in. in diameter

- campestris

$11 / 2$ to 2 in. in diameter.

2 to $2 \frac{1}{2}$ in. in diamtere.

$21 / 2$ to $3 \mathrm{in}$. in diameter.

- foliacea wheatleyi

5 to $6 \mathrm{ft}$.

- glabra

6 to $8 \mathrm{ft}$

8 to $10 \mathrm{ft}$

10 to $12 \mathrm{ft}$.

12 to $15 \mathrm{ft}$

- pendula

Three year old heads
Each Per 10 Per 100

Wisconsin Weeping Willow $1.00 \quad 7.50$

$1.00 \quad 7.50$

Thurlow Weeping Willow

$1.00 \quad 7.50$

$\begin{array}{ll} & \text { Golden Willow } \\ .75 & 6.00 \\ 1.00 & 7.50\end{array}$

European Mountain-Ash $2.00 \quad 17.50$

Common European Linden

$$
4.00 \quad 35.00
$$

$5.00 \quad 45.00$

9.00

15.00

\section{American Elm}

2.50

$3.50 \quad 30.00$

$6.00 \quad 55.00$

$8.00 \quad 70.00$

12.00

Specimen American Elm

$9.00 \quad 75.00$

$15.00 \quad 135.00$

$20.00 \quad 175.00$

3.50

7.50

12.00

2.50

Wheatley Elm

English Elm

2.50

22.50

$3.50 \quad 30.00$

$6.00 \quad 55.00$

$12.00 \quad 100.00$

Camperdown Elm

\section{DECIDUOUS FLOWERING AND ORMENTAL SHRUBS}

ABELIA grandiflora

18 to 24 in

Each Per 10 Per 100

$\begin{array}{ll}\text { Glossy Abelia } \\ 1.25 & 10.00\end{array}$

ACANTHOPANAX pentaphyllum

2 to $3 \mathrm{ft}$.

5. Aralia

3 to $4 \mathrm{ft}$.

$5.00 \quad 45.00$

ALTHEA [See HIBISGUS syriacus]

AMELANCHIOR canadensis [botryapium]

15 to 18 in.

$.60^{5.00}$ Juneberry

18 to 24 in.

$\begin{array}{lll}.75 & 6.00 & 50.00\end{array}$

AMORPHA canescens

12 to 15 in.

$.756 .50^{\text {Leadplanr }}$ 
AMORPHA-continued

- fruticosa

2 to $3 \mathrm{ft}$

3 to $4 \mathrm{ft}$
Each Per 10 Per 100

\begin{tabular}{ccc}
.65 & \multicolumn{2}{c}{ Indigobusy } \\
.65 & 5.50 & 45.00
\end{tabular}

$.75 \quad 6.50$

AMYGDALUS communis

18 to 24 in

Pink and White Flowering Amond

- persica 1.25

18 to 24 in

Pink and White Flowering Peach

2 to $3 \mathrm{ft}$.

$$
1.50 \quad 13.50
$$

$2.00 \quad 17.50$

ARALIA spinosa

2 to $3 \mathrm{ft}$.

Deoils-Walkingstick

4 to $5 \mathrm{ft}$.

$1.00 \quad 9.00$

$1.50 \quad 13.50$

ARONIA arbutifolia

2 to $3 \mathrm{ft}$.

Red Chokeberry

$.75 \quad 6.50$

- melanocarpa

2 to $3 \mathrm{ft}$.

Black Chokeberry

$.75 \quad 6.50$

BACCHARIS hamilifolia

2 to $3 \mathrm{ft}$.

Groundselbush

$\begin{array}{ll}.75 & 6.50\end{array}$

\section{BERBERIS thunbergi}

15 to 18 in

18 to 24 in

2 to $3 \mathrm{ft}$.

$50 \begin{array}{rr}\text { Japanese Barberry } \\ 4.00 & 30.00\end{array}$

$\begin{array}{lll}.60 & 5.00 \quad 40.00\end{array}$

$\begin{array}{lll}.75 & 6.00 \quad 50.00\end{array}$

- minor

12 to 15

.75

Box Barberry

6.50

Wilson Barberry

12 to 15 in

1.50

BUDDLEIA davidi veitchi

One year old.

Two years old.

- lindleyana

two years old.

Veitch Butterflybush

$.60 \quad 5.00$

$.75 \quad 6.00$

Lindley Butterfybush 1.00

Truedwarf Box

$\begin{array}{lll}.50 & 4.00 & 25.00\end{array}$

$\begin{array}{lll}.75 & 6.00 \quad 45.00\end{array}$

8 to 12 in

Chinese Beauty Berry

\begin{tabular}{ll}
$.75 \quad 6.50$ \\
\hline
\end{tabular}

18 to 24 in

Common Sweetshrub

$.65 \quad 5.50$

$.75 \quad 6.50$

15 to 18 in

Siberian Pea-Tree

$.60 \quad 5.00$

$\begin{array}{ll}.75 & 6.50\end{array}$

2 to $3 \mathrm{ft}$.

Common Bluebeard $\begin{array}{ll}65 & 6.00\end{array}$

Two years old.

Common Buttonbush $.75 \quad 6.50$

18 to 24 in

\section{White Fringetree}

3 to $4 \mathrm{ft}$.

2.00

CLETHRA alnifolia

10 to 12 in.

18 to 24 in

Summersweet

6.00

6.50

Common Bladder-senna .60

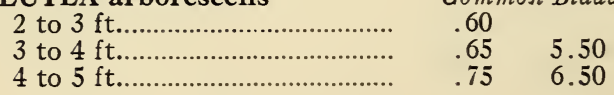


CORNUS amomum

6 to $8 \mathrm{ft}$.

- baileyi

6 to $8 \mathrm{ft}$

- paniculata

2 to $3 \mathrm{ft}$.

3 to $4 \mathrm{ft}$.

- stolonifera lutea

2 to $3 \mathrm{ft}$.

\section{COTONEASTER dielsiana}

15 to 18 in.

- horizontalis

12 to 18 in

\section{CYDONIA japonica}

18 to 24 in

2 to $3 \mathrm{ft}$.

CYTISUS scoparius

Two years old.

DAPHNE cneorum

Two years old...

\section{DEUTZIA gracilis}

12 to 15 in

15 to 18 in

18 to 24 in

\section{- rosea}

18 to 24 in.

- lemoinei

15 to 18 in

18 to 24 in

2 to $3 \mathrm{ft}$.

- scabra crenata

2 to $3 \mathrm{ft}$

3 to $4 \mathrm{ft}$.

- - Pride of Rochester

3 to $4 \mathrm{ft}$

4 to $5 \mathrm{ft}$.

\section{EUONYMUS alatus}

15 to 18 in

18 to 24 in.

2 to $3 \mathrm{ft}$.

- radicans carrierei

2 to $3 \mathrm{ft}$.

\section{EXOCHORDA grandiflora}

2 to $3 \mathrm{ft}$.

3 to $4 \mathrm{ft}$.

FORSYTHIA suspensa

2 to $3 \mathrm{ft}$.

3 to $4 \mathrm{ft}$.

- fortunei

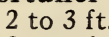

3 to $4 \mathrm{ft}$.

HALESIA tetraptera

18 to 24 in.

2 to $3 \mathrm{ft}$.
Each Per 10 Per 100

Silky Dogwood

$2.00 \quad 15.00$

Roughleaf Dogwood

$2.00 \quad 15.00$

Gray Dogwood

$\begin{array}{ll}60 & 5.00\end{array}$

$.75 \quad 6.50$

Goldentwig Dogwood $65 \quad 5.50$

Diels Cotoneaster

$1.50 \quad 12.50$

Rock Cotoneaster

$2.00 \quad 15.00$

Flowering Quince

$\begin{array}{lll}1.00 & 7.50 & 65.00\end{array}$

$1.25 \quad 10.00$

Scotch Broom

$1.00 \quad 7.50$ 12.50

Slender Deutzia

$\begin{array}{lll}.65 & 5.50 & 45.00\end{array}$

$\begin{array}{lll}.75 & 6.50 & 55.00\end{array}$

$\begin{array}{lll}1.00 & 7.50 \quad 65.00\end{array}$

Rose Panicle Deutzia

$\begin{array}{lll}.75 & 6.50 \quad 55.00\end{array}$

Lemoine Deutzia

$\begin{array}{lll}.50 & 4.50 & 40.00\end{array}$

$\begin{array}{lll}.65 & 5.50 & 45.00\end{array}$

$\begin{array}{lll}.75 & 6.50 & 55.00\end{array}$

Fuzzy Deutzia

$\begin{array}{lll}.60 & 4.50 & 37.50\end{array}$

$\begin{array}{lll}65 & 5.00 \quad 40.00\end{array}$

Pride of Rochester Deutzia

$\begin{array}{lll}.65 & 5.00 & 40.00\end{array}$

$\begin{array}{lll}.75 & 6.00 & 50.00\end{array}$

Winged Euonymus

$\begin{array}{lll}.75 & 6.50 & 55.00\end{array}$

$1.00 \quad 8.50$

$1.50 \quad 12.50$

Glossy Wintercreeper $1.50 \quad 12.50$

Common Pearlbush $\begin{array}{ll}.75 & 6.50\end{array}$

$1.00 \quad 8.50$

Weeping Forsythia

$\begin{array}{lll}.60 & 5.00 & 40.00\end{array}$

$.65 \quad 5.50$

Fortune Forsythia

$\begin{array}{lll}60 \quad 5.00 & 40.00\end{array}$

$\begin{array}{lll}.65 & 5.50 & 45.00\end{array}$

Great Silverbell

$\begin{array}{ll}1.00 & 9.00\end{array}$

$1.50 \quad 12.50$ 
HIBISCUS syriacus

\section{- - amplissima}

2 to $3 \mathrm{ft}$

3 to $4 \mathrm{ft}$.

4 to $5 \mathrm{ft}$

- - carena plena

2 to $3 \mathrm{ft}$.

3 to $4 \mathrm{ft}$

Rose of Sharon or Shrub Althea

- Chas. Breton

2 to $3 \mathrm{ft}$.

$.60 \quad 5.00$

3 to $4 \mathrm{ft}$

\section{- Jean de Arc}

2 to $3 \mathrm{ft}$.

$.60 \quad 5.00$

3 to $4 \mathrm{ft}$

$.75 \quad 6.50$

4 to $5 \mathrm{ft}$

$1.00 \quad 7.50$

55.00

\section{- monstruosa}

2 to $3 \mathrm{ft}$..

.60

3 to $4 \mathrm{ft}$

- totus alba

2 to $3 \mathrm{ft}$.

$.60 \quad 5.00$

3 to $4 \mathrm{ft}$

- - variegatus

2 to $3 \mathrm{ft}$

$.75 \quad 6.50$

3 to $4 \mathrm{ft}$.

1.00

8.50

HYDRANGEA arborescens grandiflora

18 to 24 in

.75

2 to $3 \mathrm{ft}$

- - sterilis

Snowhill Hydrangea

2 to $3 \mathrm{ft}$.

$\begin{array}{lll}.85 & 7.50 & 65.00\end{array}$

- paniculata grandflora Peegee or Panicled Hydrangea

18 to 24 in

2 to $3 \mathrm{ft}$.

$\begin{array}{lll}.75 & 6.50 & 55.00\end{array}$

$\begin{array}{lll}.85 & 7.50 & 65.00\end{array}$

- quercifolia

18 to 24 in.

Oakleaf Hydrangea

ILEX verticillata

18 to 24 in.. .75

Common Winterberry $\begin{array}{lll}.75 & 6.50 \quad 55.00\end{array}$

LABURNUM vulgare

2 to $3 \mathrm{ft}$.

3 to $4 \mathrm{ft}$.

Goldenchain

$\begin{array}{lll}.75 & 6.50 & 55.00\end{array}$

$1.00 \quad 7.50 \quad 65.00$

- canbyi

18 to 24 in

2 to $3 \mathrm{ft}$

Weeping Goldenchain

1.00

1.25

LESPEDEZA formosa

Three years old.

65 Purple Bushclover

\section{LIGUSTRUM amurense}

2 to $3 \mathrm{ft}$.

3 to $4 \mathrm{ft}$.

35 Amur Privet

$\begin{array}{lll}35 & 3.00 & 20.00\end{array}$

$\begin{array}{lll}.50 & 4.00 \quad 30.00\end{array}$

- ibolium

2 to $3 \mathrm{ft}$

Ibolium Privet

$\begin{array}{lll}.60 & 4.50 \quad 35.00\end{array}$

- ibota

2 to $3 \mathrm{ft}$.

Ibota Privet

3 to $4 \mathrm{ft}$.

$\begin{array}{lll}.50 & 3.50 & 25.00 \\ .60 & 4.50 & 30.00\end{array}$

- regelianum

12 to 18 in. spread

18 to 24 in. spread.

Regel Privet

.50

$4.00 \quad 30.00$

2 to $3 \mathrm{ft}$. spread

.75

$\begin{array}{ll}6.50 & 50.00 \\ 7.50 & 65.00\end{array}$

- lodense

12 to 18 in.

Dwarf Privet

$\begin{array}{lll}.50 & 4.50 & 40.00\end{array}$ 
Each Per 10 Per 100 Per 1000

- ovalifolium

12 to 18 in.

18 to 24 in.

2 to $3 \mathrm{ft}$

3 to $4 \mathrm{ft}$.

- vulgare

2 to $3 \mathrm{ft}$

3 to $4 \mathrm{ft}$

LONICERA bella albida

2 to $3 \mathrm{ft}$

3 to $4 \mathrm{ft}$.

4 to $5 \mathrm{ft}$.

- fragrantissima

2 to $3 \mathrm{ft}$

3 to $4 \mathrm{ft}$.

- morrowi

2 to $3 \mathrm{ft}$

3 to $4 \mathrm{ft}$

- pileata

12 to 15 in

- tatarica rosea

2 to $3 \mathrm{ft}$

3 to $4 \mathrm{ft}$.

4 to $5 \mathrm{ft}$

MAHONIA aquifolium

10 to 12 in

12 to 18 in

\section{PHILADELPHUS aureus}

12 to 15 in

15 to 18 in

18 to 24 in

- gordonianus

2 to $3 \mathrm{ft}$.

- grandiflorus

2 to $3 \mathrm{ft}$.

3 to $4 \mathrm{ft}$.

- lemoinei

2 to $3 \mathrm{ft}$

3 to $4 \mathrm{ft}$

- Horticultural Varieties of Lemoine's Hybrids:

- Albatre

18 to 24 in

2 to $3 \mathrm{ft}$.

- Albatross

18 to 24 in

2 to $3 \mathrm{ft}$

3 to $4 \mathrm{ft}$.

- Avalanche

18 to 24 in.

\section{- Bouquet Blanc}

18 to 24 in

2 to $3 \mathrm{ft}$.

- Dame Blanc

15 to 18 in.

2 to $3 \mathrm{ft}$

- Favorite

15 to 18 in

18 to 24 in

2 to $3 \mathrm{ft}$ !
California Privet

$$
5.00 \quad 35.00
$$

$8.00 \quad 60.00$

$12.00 \quad 100.00$

$\begin{array}{lll}2.50 & 20.00 \quad 150.00\end{array}$

Each Per 10 Per 100

European Privet $4.00 \quad 25.00$

$5.00 \quad 35.00$

White Belle Honeysuckle

$\begin{array}{lll}.50 & 4.00 & 30.00\end{array}$

$\begin{array}{lll}.65 & 5.50 & 45.00\end{array}$

$\begin{array}{lll}.75 & 6.50 & 55.00\end{array}$

Winter Honeysuckle

$\begin{array}{lll}.85 & 7.50 & 65.00\end{array}$

$\begin{array}{lll}1.00 & 9.00 \quad 75.00\end{array}$

Morrow Honeysuckle

$\begin{array}{lll}.60 & 5.00 & 40.00\end{array}$

$\begin{array}{lll}.75 & 6.50 & 55.00\end{array}$ Privet Honeysuckle
$.85 \quad 7.50$

Rosy Tartarian Honeysuckle

$\begin{array}{lll}.60 & 5.00 & 40.00\end{array}$

$\begin{array}{lll}.75 & 6.50 & 55.00\end{array}$

$\begin{array}{lll}.85 & 7.50 \quad 65.00\end{array}$

1.00 Oregon Holly

$\begin{array}{rrr}1.00 & 9.00 & 85.00\end{array}$

Golden Philadelphus

$\begin{array}{lll}.65 & 5.50 \quad 45.00\end{array}$

$\begin{array}{lll}.75 & 6.50 & 60.00\end{array}$

$.90 \quad 7.50 \quad 65.00$

Gordon Mockorange

$\begin{array}{lll}60 & 5.00 & 40.00\end{array}$

Big Scentless Mockorange

$\begin{array}{lll}.60 & 5.00 & 40.00\end{array}$

$\begin{array}{lll}.75 & 6.00 & 50.00\end{array}$

Lemoine Mockorange

$\begin{array}{lll}.75 & 6.00 & 50.00\end{array}$

$\begin{array}{lll}.85 & 7.50 & 65.00\end{array}$

$1.25 \quad 10.00$

$1.50 \quad 12.50$

1.25

$1.50 \quad 12.40$

$2.00 \quad 15.00$

1.00

$\begin{array}{lll}1.00 & 7.50 & 65.00\end{array}$

$\begin{array}{lll}1.25 & 10.00 \quad 85.00\end{array}$

$1.00 \quad 7.50$

$1.50 \quad 12.50$

$1.00 \quad 8.50$

1.50

2.00 
PHILADELPHUS-continued

- Galatea

2 to $3 \mathrm{ft}$.

- Girandole

12 to 15 in.

- Glacier

18 to 24 in.

2 to $3 \mathrm{ft}$.

\section{- Manteau d'Hermine}

18 to 24 in.

2 to $3 \mathrm{ft}$.

- Mt. Blanc

15 to 18 in.

18 to 24 in.

2 to $3 \mathrm{ft}$.

- Nuee Fleuri

2 to $3 \mathrm{ft}$.

- nivalis

2 to $3 \mathrm{ft}$

3 to $4 \mathrm{ft}$.

4 to $5 \mathrm{ft}$.

\section{- Norma}

18 to 24 in

2 to $3 \mathrm{ft}$.

3 to $4 \mathrm{ft}$.

- purpurea maculatus

15 to 18 in

- pyramidal

2 to $3 \mathrm{ft}$.

- Romeo

15 to 18 in

- Sybile

18 to 24 in

\section{- Virginal}

18 to 24 in.

2 to $3 \mathrm{ft}$

3 to $4 \mathrm{ft}$.

- Zeyheri

18 to 24 in.

2 to $3 \mathrm{ft}$.

3 to $4 \mathrm{ft}$.

PRUNUS cerasifera pissardi

4 to $5 \mathrm{ft}$.

- triloba

3 to $4 \mathrm{ft}$.

PYRACANTHA coccinea lalandi 18 to 24 in.

RHAMNUS cathartica

2 to $3 \mathrm{ft}$.

3 to $4 \mathrm{ft}$.

4 to $5 \mathrm{ft}$.

- frangula 4 to $5 \mathrm{ft}$.

RHODOTYPUS kerrioides

18 to 24 in.

2 to $3 \mathrm{ft}$.

RHUS canadensis

2 to $3 \mathrm{ft}$.

- copallina

2 to $3 \mathrm{ft}$
Each Per 10 Per 100

$1.50 \quad 12.50$

$1.25 \quad 10.00$

$1.50 \quad 12.50$

$2.00 \quad 15.00$

$\begin{array}{lll}.65 & 5.00 & 40.00\end{array}$

$.75 \quad 6.50$

$\begin{array}{lll}.50 & 4.50 \quad 40.00\end{array}$

$\begin{array}{lll}.65 & 6.00 \quad 50.00\end{array}$

$\begin{array}{lll}.75 & 6.50 & 55.00\end{array}$

$1.50 \quad 12.50$

$\begin{array}{lll}.50 & 4.50 \quad 40.00\end{array}$

$\begin{array}{lll}.65 & 5.50 & 45.00\end{array}$

$\begin{array}{lll}.75 & 6.50 & 50.00\end{array}$

$\begin{array}{lll}1.00 & 9.00 & 85.00\end{array}$

$\begin{array}{lrr}1.50 & 12.50 & 100.00\end{array}$

$\begin{array}{lll}2.00 & 15.00 & 125.00\end{array}$

$2.00 \quad 15.00 \quad 125.00$

$1.50 \quad 12.50$

$1.25 \quad 10.00$

1.50

$\begin{array}{lll}1.25 & 10.00 & 85.00\end{array}$

$\begin{array}{lll}1.50 & 12.50 & 100.00\end{array}$

$2.00 \quad 15.00$

$\begin{array}{lll}.50 & 4.00 & 30.00\end{array}$

$\begin{array}{lll}.60 & 5.00 \quad 40.00\end{array}$

.75

Purpleleaf Plum $2.00 \quad 15.00$

Flowering Plum

$2.50 \quad 22.50$

Laland Firethorn

2.50

Common Buckthorn $.60 \quad 5.00$

$\begin{array}{lll}.75 & 6.50 & 55.00\end{array}$

$1.00 \quad 7.50 \quad 60.00$

Glossy Buckthorn

5.50 Jetbead

$.65 \quad 5.50$

$\begin{array}{ll}.75 & 6.50\end{array}$

Fragrant Sumac .65 5.50

Shining Sumac .75 6.50 
- cotinus

3 to $4 \mathrm{ft}$.

4 to $5 \mathrm{ft}$

\section{RIBES alpinum}

15 to $18 \mathrm{in}$.

18 to 24 in

ROSA blanda

2 years old.

- humilis

2 years old.

- rubrifolia

2 years old

-rugosa

2 years old

- setigera

2 years old

\section{SALIX caprea}

3 to $4 \mathrm{ft}$.

4 to $5 \mathrm{ft}$

- incana

2 to $3 \mathrm{ft}$

3 to $4 \mathrm{ft}$.

4 to $5 \mathrm{ft}$.

SAMBUCUS canadensis aurea

4 to $5 \mathrm{ft}$.

- pubens

3 to $4 \mathrm{ft}$.

SORBARIA sorbifolia

3 to $4 \mathrm{ft}$

SPIRAEA arguta multiflora

2 to $3 \mathrm{ft}$.

3 to $4 \mathrm{ft}$

- billiardi

3 to $4 \mathrm{ft}$.

- bumalda

12 to 15 in

15 to 18 in

18 to 24 in

- anthony waterer

15 to 18 in

18 to 24 in

- froebeli

2 to $3 \mathrm{ft}$.

- margaritae

18 to 24 in

2 to $3 \mathrm{ft}$

- prunifolia

2 to $3 \mathrm{ft}$

3 to $4 \mathrm{ft}$

- salicifolia

3 to $4 \mathrm{ft}$.

- thunbergi

2 to $3 \mathrm{ft}$

- vanhouttei

18 to 24 in

2 to $3 \mathrm{ft}$.

3 to $4 \mathrm{ft}$

4 to $5 \mathrm{ft}$.
Each Per 10 Per 100

Common Smoketree

$\begin{array}{lll}1.00 & 8.50 & 75.00\end{array}$

$1.50 \quad 12.50$

Mountain Currant
.65
5.50

$.75 \quad 6.50$

Meadow Rose

$\begin{array}{lll}60 & 4.50 \quad 35.00\end{array}$

Pasture Rose

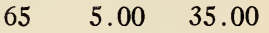

Redleaf Rose

$1.00 \quad 7.50$

$60 \quad \begin{array}{r}\text { Rugosa Rose } \\ 4.50 \quad 35.00\end{array}$

Prairie Rose

$\begin{array}{lll}.65 & 5.00 \quad 35.00\end{array}$

Goat Willow

$6.50 \quad 50.00$

$7.50 \quad 60.00$

Rosemary Willow

$\begin{array}{lll}.60 & 5.00 & 40.00 \\ .75 & 6.50 & 50.00\end{array}$

$1.00 \quad 7.50 \quad 65.00$

Golden American Elder $\begin{array}{ll}.75 & 6.50\end{array}$

.75

Scarlet Elder 6.50

.85

False Spirea 7.50

Garland Spirea

$\begin{array}{lll}65 & 6.00 & 50.00\end{array}$

$\begin{array}{lll}.75 & 6.50 & 60.00\end{array}$

Billiard Spirea

$\begin{array}{lll}.65 & 6.00 \quad 50.00\end{array}$

Bumalda Spirea

$\begin{array}{lll}.55 & 6.00 & 50.00\end{array}$

$.65 \quad 6.50$

$1.00 \quad 8.50$

Dwarf Pink Spirea

$\begin{array}{lll}.65 & 6.00 & 50.00\end{array}$

$\begin{array}{lll}.75 & 6.50 & 60.00\end{array}$

Froebel Spirea

$\begin{array}{lll}.85 & 7.50 & 65.00\end{array}$

Margarita Spirea

1.00

1.50

Old-Fashioned Bridalwreath

$\begin{array}{lll}.75 & 6.50 & 55.00\end{array}$

$1.00 \quad 7.50$

Willowleaf Spirea

$\begin{array}{ll}.75 & 6.50\end{array}$

Thunber
7.50

unberg Spirea

Bridalwreath

$\begin{array}{lll}.50 & 4.50 \quad 40.00\end{array}$

$\begin{array}{lll}.65 & 5.50 & 45.00\end{array}$

$\begin{array}{lll}.75 & 6.50 & 55.00\end{array}$

$\begin{array}{lll}1.00 & 7.50 & 65.00\end{array}$ 


\section{STEPHANANDRA flexuosa}

15 to 18 in

SYMPHORIGARPOS racemosus

2 to $3 \mathrm{ft}$.

3 to $4 \mathrm{ft}$.

- vulgaris

2 to $3 \mathrm{ft}$.

3 to $4 \mathrm{ft}$.

\section{SYRINGA chinensis}

2 to $3 \mathrm{ft}$

- persica

2 to $3 \mathrm{ft}$.

- vulgaris

2 to $3 \mathrm{ft}$

3 to $4 \mathrm{ft}$.

- alba

2 to $3 \mathrm{ft}$.

3 to $4 \mathrm{ft}$.

- Horticultural varieties of $S$. vulgaris

2 to $3 \mathrm{ft}$.

Aline Mocqueris

Mme, Casimer Perier

Charles Joly

Charles the Tenth

Congo

Dr. Masters

Marie Legraye

President Grevy

Vestale

TAMARIX pentandra

3 to $4 \mathrm{ft}$.

4 to $5 \mathrm{ft}$

\section{VIBURNUM americanum}

2 to $3 \mathrm{ft}$.

3 to $4 \mathrm{ft}$.

- dentatum

15 to 18 in

18 to 24 in.

- lantana

2 to $3 \mathrm{ft}$.

3 to $4 \mathrm{ft}$.

- molle

15 to 18 in.

\section{- opulus}

2 to $3 \mathrm{ft}$

3 to $4 \mathrm{ft}$.

- opulus sterile

2 to $3 \mathrm{ft}$.

3 to $4 \mathrm{ft}$.

- tomentosum

2 to $3 \mathrm{ft}$.

3 to $4 \mathrm{ft}$.

VITEX agnus-castus

Three years old

\section{WEIGELA floribunda}

18 to 24 in

- rosea

18 to 24 in

2 to $3 \mathrm{ft}$.

3 to $4 \mathrm{ft}$

4 to $5 \mathrm{ft}$.
Each Per 10 Per 100

Cutleaf Stephanandra

$\begin{array}{lll}.75 & 6.50 & 55.00\end{array}$

Common Snowberry

$\begin{array}{lll}.65 & 5.50 & 40.00\end{array}$

$\begin{array}{lll}.75 & 6.50 & 50.00\end{array}$

Coralberry
$.65 \quad 5.50 \quad 45.00$

$.75 \quad 6.50$

1.00 Chinese Lilac

Persian Lilac

1.00

Common Lilac

$\begin{array}{lll}.50 & 4.50 & 40.00\end{array}$

$\begin{array}{lll}.65 & 5.50 \quad 45.00\end{array}$

Common White Lilac

$\begin{array}{lll}.50 & 4.50 & 40.00\end{array}$

$\begin{array}{lll}.65 & 5.50 & 45.00\end{array}$

French Lilac 12.50

Fivestamen Tamarix

$.75 \quad 6.50$

$1.00 \quad 7.50$

American Cranberrybush

$\begin{array}{lll}.75 & 6.50 & 50.00\end{array}$

$\begin{array}{lll}.85 & 7.50 \quad 65.00\end{array}$

$65 \quad$ Arrowwood

$.65 \quad 5.50$

$.75 \quad 6.50$

Wayfaring-tree

$\begin{array}{ll}.75 & 6.50\end{array}$

$.85 \quad 7.50$

Kentucky Viburnum $.65 \quad 5.50$

Highbush Cranberr

$.60 \quad 5.00$

$.75 \quad 6.50$

Common Snowball

$\begin{array}{ll}.75 & 6.50\end{array}$

$.85 \quad 7.50$

Doublefile Viburnum

$.75 \quad 6.50$

$1.00 \quad 7.50$

75 Lilac Chaste-tree 6.50

Crimson Weigela

$.75 \quad 6.50$

$50 \quad$ Pink Weigela

$\begin{array}{lll}.65 & 5.00 & 45.00\end{array}$

$\begin{array}{lll}.75 & 6.50 & 55.00\end{array}$

$1.00 \quad 7.50$ 
Horticultural varieties of Weigela:

- Eva Rathke 15 to 18 in

2 to $3 \mathrm{ft}$

Each Per 10 Per 100

3 to $4 \mathrm{ft}$

$\begin{array}{ll}.75 & 6.50\end{array}$

$1.00 \quad 7.50$

$\begin{array}{lll}1.25 & 10.00 \quad 90.00\end{array}$

hybrida candida

12 to 18 in.................................. . .65

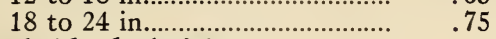

- hybrida desboisi

3 to $4 \mathrm{ft}$.

White Weigela

4 to $5 \mathrm{ft}$

.75

Desbois Weigela

- hybrida nana variegata

Variegated Dwarf Weigela

12 to 15 in

$.65 \quad 5.50$

2 to $3 \mathrm{ft}$.

$1.00 \quad 7.50$

\section{VINES AND CLIMBERS}

\section{ARISTOLOCHIA sipho}

Three years old.

\section{- tomentosa}

Two years old.

AMPELOPSIS heterophylla

Two years old.

- quinquefolia

Two years old

- - engelmanni

Two years old.

- veitchi [tricuspidata]

Two years old.

BIGNONIA radicans

Two years old.

Three years old..

CELASTRUS orbiculatus

Two years old.

- scandens

Three years old.

\section{CLEMATIS paniculata}

Two years old.

Three years old.

- Horticultural Varieties:

Two years old.

- Henryi

- Jackmanii

- Madame Edouard Andre

EUONYMUS compacta

Two years old.

- radicans

Two years old.

\section{- - acutus}

Two years old.

\section{- variegata}

Two years old

\section{- - vegetus}

Two years old.

\section{HEDERA helix}

Two years old.

LONICERA japonica halliana

Two years old.
Each Per 10 Per 100

Dutchmans Pipe

$1.50 \quad 12.50$

Common Dutchmans Pipe $\begin{array}{ll}.50 & 4.00\end{array}$

Porcelain Ampelopsis

$\begin{array}{lll}.75 & 6.50 & 50.00\end{array}$

Virginia Creeper

$\begin{array}{lll}.50 & 4.00 & 35.00\end{array}$

Engelmann Creeper

$\begin{array}{lll}.75 & 6.50 \quad 50.00\end{array}$

Boston Ivy
$.75 \quad 6.50 \quad 50.00$

Trumpetcreeper

$.60 \quad 5.00$

$\begin{array}{ll}.75 & 6.50\end{array}$

Oriental Bittersweet $\begin{array}{lll}.75 & 6.50 & 55.00\end{array}$

American Bittersweet $\begin{array}{lll}.75 & 6.50 & 50.00\end{array}$

Sweet Autumn Clematis $\begin{array}{lll}.50 & 4.50 & 40.00\end{array}$

$\begin{array}{ll}.75 & 6.50\end{array}$

Large Flowering Clematis $1.00 \quad 7.50$ $\begin{array}{ccr} & & \text { Wintercreeper } \\ .75 & 6.50 & 50.00 \\ & \text { Wintercreeper } \\ .75 & 6.50 & 50.00 \\ \text { Sharpleaf } & \text { Wintercreeper } \\ .75 & 6.50 & 50.00\end{array}$

$V$ ariegated Wintercreeper

$\begin{array}{lll}1.00 & 8.50 & 75.00\end{array}$

Bigleaf Wintercreeper

$\begin{array}{lll}1.00 & 8.50 \quad 75.00\end{array}$

English Ivy
$.75 \quad 6.00 \quad 50.00$

Hall Japan Honeysuckle $\begin{array}{lll}.50 & 4.00 \quad 30.00\end{array}$ 
LONICERA - continued

- sempervirens

Two years old.

LYGIUM chinense

Two years old.

WISTERIA japonica

Two years old

- multijuga

Two years old

- sinensis

Two years old [seedlings]

Two years old [grafted].
Each Per 10 Per 100

Trumpet Honeysuckle

$\begin{array}{lll}.50 & 4.00 & 30.00\end{array}$

Chinese Matrimony Vine $\begin{array}{ll}60 & 5.00\end{array}$

Lavender Wisteria

12.50

White Longcluster Wisteria

\begin{tabular}{ll}
$1.50 \quad 12.50$ \\
\hline
\end{tabular}

Purple Chinese Wisteria

.756 .00

$1.50 \quad 12.50$

\section{ROSES}

Strong, two-year old, field grown plants.

Each Per 10 Per 100

Hybrid Tea Roses

$\begin{array}{lll}1.00 & 9.00 & 75.00\end{array}$

Varieties:

Cochet-Light Pink

Columbia-Large Pink

Gruss an Teplitz-Bright Grimson

Hoosier Beauty-Red

Killarney-Pink

Hoosier Beauty-Red

Killarney-Pink

Killarney Brilliant-Light Pink

La France-Silvery Pink

Los Angeles-Pink shaded with gold

Mad. Caroline Testout-Satiny Pink

Mad. Eduard Herriott-Copper

Mrs. Aaron Ward-Deep Yellow

Ophelia-Salmon flesh

Premier-Deep Rose

Radiance-Rosy Carmine

Red Radiance-Brilliant Crimson

Souv. de Glaudius Pernet-Sunflower yellow

Willowmere-Rich Pink

Hybrid Perpetual Roses................. $\quad 1.00 \quad 9.00 \quad 75.00$

Varieties:

Eugene Furst-Dark Red Magna Charta-Pink Frau Karl Druschki-White Mrs. John Laing-Pink General Jacqueminot-Red Paul Neyron-Pink George Ahrends-Soft Pink Ulrich Brunner-Red

Climbing and Rambling Roses

Varieties:

American Pillar-Single

Pink, yellow center............. $\quad .75 \quad 6.50$

Aviateur de Bleriot-

Saffron yellow.

$1.00 \quad 7.50$

Bess Lovett-Light crimson $\quad 1.25 \quad 10.00$

Christine Wright-Wild-

Roses Pink

$1.25 \quad 1.000$

Climbing American Beauty

- Large Pink

$1.00 \quad 7.50$

Climbing Gruss an Teplitz-Grimson

$1.00 \quad 7.50$

Grimson RamblerCrimson.

Dr. W. Van Fleet-

Deep Flesh

$1.00 \quad 7.50$

Dorothy Perkins-Pink

$.75 \quad 5.00$


Each Per 10 Per 100

Excelsa-Red

$\begin{array}{rr}.75 & 5.00 \\ 1.00 & 7.50 \\ 1.00 & 7.50 \\ & \\ 1.50 & 12.50 \\ 1.00 & 7.50\end{array}$

Gardenia-Bright Yellow....

Hiawatha-Carmine..

Paul's Scarlet-Vivid

Scarlet.

$1.00 \quad 7.50$

Silver Moon-Large White..

Miscellaneous Roses

Varieties:

Baby Rambler-Pink and Red.

Harrison's Yellow-Single

Yellow.

$1.00 \quad 8.50$

Hugonis-Single Yellow......

Moss Roses.

$1.00 \quad 8.50$

$2.00 \quad 17.50$

$1.00 \quad 8.50$

Rugosas in variety.

$1.00 \quad 8.50$

\section{HARDY HERBACEOUS PERENNIALS}

* indicates plants suitable for rockery or alpine gardens. Sizes following variety indicate height at maturity.

ACHILLEA eupatorium [ Yarrow]

Each Per 12 Per 100

yellow, $4 \mathrm{ft}$.

$\begin{array}{lll}.30 & 3.00 & 20.00\end{array}$

- ptarmica, [The Pearl] white, $2 \mathrm{ft}$... $\quad .20 \quad 2.00 \quad 15.00$

* - tomentosa, yellow, 6 to 8 in.......... $\quad .25 \quad 2.50 \quad 17.50$

ACONITUM napellus [Monkshood] pale blue, $3-4 \mathrm{ft}$.............................. $.50 \quad 5.00$

*AL YSSUM rostratum [ Yellowhead Alyssum] yellow, 9 in............. $\quad .25 \quad 2.50 \quad 15.00$

* - saxatile compactum [Goldentuft] yellow, $1 \mathrm{ft}$................. $.25 \quad 2.50 \quad 17.50$

AETHIONEMA grandiflora [ $\mathrm{Per}$ sian Candytuft] pink, 9 in............... $\quad .40 \quad 4.00 \quad 30.00$

ANCHUSA italica, Dropmore, [Italian Bugloss] blue, $4 \mathrm{ft}$.

$.25 \quad 2.50 \quad 17.50$

ANEMONE japonica [Windflower]

- "Queen Charlotte" pink, $2 \mathrm{ft}$......... $\quad .50 \quad 5.00$

— Whirlwind, white, $2 \mathrm{ft}$..................... $\quad .50 \quad 5.00$

AQUILEGIA coerulea [Colorado Columbine] blue, 18 in.

$\begin{array}{lll}.30 & 3.00 & 20.00\end{array}$

- chrysantha, [Golden Columbine] yellow, 18 in.

$\begin{array}{lll}.30 & 3.00 & 20.00\end{array}$

- Long Spurred Hybrids, mixed colors, $2 \mathrm{ft}$..

.30

$3.00 \quad 20.00$

- Mrs. Scott Elliott Hybrids, mixed colors, $2 \mathrm{ft}$.

* ARABIS alpina [ Rockcress] white, 6 in

ARMERIA laucheana rosea, [Sea Pink or Thrift] rose, 4 in......... $.35 \quad 3.50 \quad 27.50$

- maratima [Cushion Pink] purple, 4 in.

ARTEMISIA lactiflora

[ $W$ ormwood] white, $3 \mathrm{ft}$.

* ASTER alpinus albus [Rock Aater] white, 6 in.

* - Goliath, blue

- amellus elegans [Italian Aster] lavender, $2 \mathrm{ft}$.... 
ASTER-continued

Each Per 12 Per 100

- tataricus [Tartarian Aster] violet, $6 \mathrm{ft}$.

.25

- Brussels .................................. .25

— Elta, pale lilac...................................... . .25

- Feltham Blue, blue............................ . .25

- Glory of Colwall, ageratum-blue... . .25

*-Mauve Cushion, mauve, $2 \mathrm{ft}$...... $\quad .25$

- Miss Eisele.

- novae-angliae roseum superbum, red...

.25

.35

.35

.30

.30

.30

$2.50 \quad 17.50$

$2.50 \quad 17.50$

$2.50 \quad 17.50$

$2.50 \quad 17.50$

$2.50 \quad 17.50$

$2.50 \quad 17.50$

$2.50 \quad 17.50$

3.50

3.50

- novaebelgi [Climax] lavenderblue, $5 \mathrm{ft}$.

- - St. Egwin, rosy-pink, $3 \mathrm{ft}$.

- Perry's White, white.

ASTILBE [see SPIRAEA]

BAPTISIA australis [Wild Indigo] dark blue, $2 \mathrm{ft}$.

$3.00 \quad 20.00$

$3.00 \quad 20.00$

$3.00 \quad 20.00$

.40

$4.00 \quad 30.00$

BOCCONIA cordata [Plume Poppy] white, $6 \mathrm{ft}$..

$2.50 \quad 17.50$

.25

$2.50 \quad 17.50$

Chamomile] pirik, $5 \mathrm{ft}$.

CALAMINTHE alpina [Calamint] purple, 6 in.

.30

$3.00 \quad 20.00$

.30

$3.00 \quad 20.00$ thian Harebell] blue, 8 in.

$2.50 \quad 17.50$ pink and white, $3 \mathrm{ft}$.

$2.50 \quad 17.50$

.50

.25

$5.00 \quad 45.00$ [Blue Spirea] lavender, $3 \mathrm{ft}$..

CATANANCHE caerulea [Cupid's Dart] deep blue, $2 \mathrm{ft}$.

$2.50 \quad 17.50$

.30

$3.00 \quad 20.00$ [Snow-in-Summer] white, 6 in

GHELONE 1yoni [Shellflower] purplish-red, $2 \mathrm{ft}$..

$3.50 \quad 27.50$

$2.50 \quad 17.50$

.30

$3.00 \quad 20.00$ red, white and yellow.

$3.50 \quad 27.50$

$3.50 \quad 27.50$

$3.50 \quad 27.50$

$3.50 \quad 27.50$

$3.50 \quad 27.50$

$3.50 \quad 27.50$

$3.50 \quad 27.50$

$3.50 \quad 27.50$

Oconto, pure white............................ . .35

October Gold, golden bronze........... . . 35

Rose Travena, very large deep rose-pink.

Snowdrop, pure white dwarf button

Tints of Gold, bronze, large.

$3.50 \quad 27.50$

$3.50 \quad 27.50$

$3.50 \quad 27.50$

$\begin{array}{ll}3.50 & 27.50\end{array}$

White Totty, white

- maximum [Shasta Daisy] Alaska, white, $2 \mathrm{ft}$.......

- - Etoile d'Or...

- - Glory of Wayside.

- Mrs. C. Lowthian Bell
$2.50 \quad 17.50$

$3.50 \quad 27.50$

$3.50 \quad 27.50$

$\begin{array}{ll}3.50 & 27.50\end{array}$ 
*CONVALLARIA majalis [Lily-of-

Each Per 12 Per 100

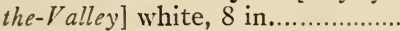

DELPHINIUM belladonna [Lark-

spur] light blue, $21 / 2 \mathrm{ft}$.................. . . 30

$\begin{array}{lll}.15 & 1.50 \quad 8.00\end{array}$

— bellamosa, dark blue, $2 \frac{1}{2} \mathrm{ft}$.......... $\quad .30 \quad 3.00 \quad 20.00$

$\begin{array}{lllll}\text { - chinense, gentian-blue, } 2 \mathrm{ft} \text {............. } & .25 & 2.50 & 17.50\end{array}$

- English Hybrids, mixed colors, very fine, 2 to $4 \mathrm{ft}$..

$\begin{array}{lll}.35 & 3.50 & 17.50\end{array}$

DESMODIUM penduliflorum

[Tick Trefoil] purplish red, $3 \mathrm{ft} . \ldots . . \quad .50 \quad 5.00 \quad 37.50$

DIANTHUS barbatus [SweetWilliam] mixed colors, 18 in.......... .20

$2.00 \quad 15.00$

— Newport Pink, alsmon-rose, 18 in. $\quad .20 \quad 2.00 \quad 15.00$

- Scarlet Beauty, rich deep scarlet, 18 in

$.20 \quad 2.00 \quad 15.00$

* - caesius grandiflora [Cheddar $P$ ink] rose, 6 in

.30

$3.00 \quad 20.00$

*- deltoides [Maiden Pink] crimson, 8 in.

- plumarius [Garden Pink] mixed color, double and single.

DICENTRA [DIEL YTRA] eximea [Fringed Bleeding Heart] 18 in........

- spectabilis [Bleedingheart] pink $2 \mathrm{ft}$

DIGITALIS gloxiniaeflora $[F \circ x-$ glove] mixed colors, $3 \mathrm{ft}$......

$4.00 \quad 30.00$

$\begin{array}{lll}.60 & 6.00 & 45.00\end{array}$

DORONICUM caucasicum

[Leopardbane] yellow, $3 \mathrm{ft}$...............

ELYMUS glaucus [ $W$ ild Rye]...

$.30 \quad 3.00$

FUNKIA subcordata grandiflora [Plaintain Lily] white, $2 \mathrm{ft}$.

- variegata [ $V$ ariegated-leafed
Plaintain Lily] blue, 12 in.

GAILLARDIA grandiflora compacta [Blanket Flower] red-yellow.

$\begin{array}{lll}.40 \quad 5.00 & 37.50\end{array}$

$.40 \quad 4.00 \quad 30.00$

$\begin{array}{lll}.25 & 2.50 & 17.50\end{array}$

- portola, orange red, 18 in...

$.50 \quad 5.00$

GRASSES:

ERIANTHUS ravennae [ $P$ lume

Grass] green, $12 \mathrm{ft}$.

EULALIA gracillima univittata [Japan Rush] green, $6 \mathrm{ft}$.

— japonica [Eulalia] green $6 \mathrm{ft}$......

- variegata [ $V$ ariegated

- - zebrina [Zebra Grass] green yellow cross stripes, $7 \mathrm{ft}$.

$5.00 \quad 37.50$

*FESTUGA glauca [Blue Fescue Grass] light blue, 12 in.

GYPSOPHILA paniculata [Baby's Breath] white, $3 \mathrm{ft}$.

*- repens [Creeping Baby's Breath] white and pink, trailing

*HELENIUM autumnale rubrum [Sneezewort $]$ ox-blood-red, $5 \mathrm{ft}$........

- Riverton Gem, Terra-cotta and Riverton Beauty; [lemon-yellow, 5 feet. 
HELIANTHEMUM mutabile

Each Per 12 Per 100

[Sunrose] golden yellow, 18 in

HELIOPSIS pitcheriana [ $P$ itcher

$Z_{i n n i a]}$ golden yellow, $2 \mathrm{ft}$.

.25

$2.50 \quad 17.50$

.20

$2.00 \quad 15.00$

- scarbra zinnaeflora [ Hardy

Zinnia] chrome-yellow, $3 \mathrm{ft}$.

.20

$2.00 \quad 15.00$

HEMEROCALLIS aurantiaca [Orange Day Lily].

.35

.35

$3.50 \quad 27.50$

- citrina [Citron Day Lily].

$3.50 \quad 27.50$

- dumortieri [Early Day Lily]........... $\quad .35$

— fulva [Tawny Day Lily]...................... . . .35

- Gold Dust.

$3.50 \quad 27.50$

$3.50 \quad 27.50$

$\begin{array}{lll}.35 & 3.50 & 27.50\end{array}$

- kwanso flore plena, golden bronze, $3 \mathrm{ft}$.

- luteola [Golden Daylily].

$3.50 \quad 27.50$

- middendorfi major [Amur Daylily] orange yellow, $2 \mathrm{ft}$.

HEUCHERA brizoides [Pinkbells] pink, 18 in

- sanguinea [Coralbells] bright crimson, 18 in.

HIBISCUS [Mallow] mixed color, white, pink and red, $4 \mathrm{ft}$.

HOLLYHOCKS [Althea rosea] double mixed, 4 to $5 \mathrm{ft}$.

- Newport Pink, bright salmon pink, 5 feet.

$2.00 \quad 15.00$

HOSTA [see FUNKIA]

HYPERICUM calycinum, yellow,

8 in.

— kalmianum [ Kalm Hypericum]..... $\quad .50$

- moserianum [St. John's Wort] golden yellow, $2 \mathrm{ft}$.

- patulum Henryi [Japanese

$$
\text { Hypericum]. }
$$

*IBERIS sempervirens [Evergreen

$$
\text { Candytuft] white, } 8 \text { in.. }
$$

*IRIS cristata [Crested Iris] amethyst-blue, 3 in.

- germanica [German Iris] in the following varieties:

Aurea, golden yellow.

Alcazar, deep purple with bronzeveined throat

Archeveque, violet, $2 \mathrm{ft}$.

Caprice, rosy red, $2 \mathrm{ft}$.

Fairy, white, delicately bordered with pale blue, tall.

Gypsy Queen, soft bronze................ . .25

Her Majesty, rose, $2 \mathrm{ft}$.

Isoline, pink and old rose with.... shadings, $3 \mathrm{ft}$.

Juniata, mauve to magnanese violet.

King, lemon yellow with maroon falls, $2 \mathrm{ft}$..

Kochii, blackish purple, $2 \mathrm{ft}$. 
IRIS-continued

Lent A. Williamson, royal purple with yellow beard.

Lord of June, lavender blue

Lohengrin, mauve to chinese violet, 30 in

Lorely, yellow and raisin purple, 2 feet.

Madame Chereau, white penciled blue.

Monsignor, violet and purple, deep veinings, 30 in.

Mrs. H. A. Darwin, with purple veining, $2 \mathrm{ft}$.

Mrs. Neubrenner, deepest of the yellows, 20 in.

Each Per 12 Per 100

2.50

2.00

.25

$2.50 \quad 20.00$

.25

2.50

20.00

.25

$2.50 \quad 20.00$

.30

3.00

.25

$2.50 \quad 20.00$

.30

$3.00 \quad 20.00$

Neptune, violet and deep purple, $3 \mathrm{ft}$..

Pallida Dalmatica, lavender violet, 40 in.

$1.25 \quad 10.00$

.30

3.00

Parc de Nuilly, deep violet blue, 30 in.

$3.50 \quad 27.50$

Parisiana, white dotted and frilled violet, 30 in.

Quaker Lady, olive buff, 30 in

Rhein Nixe, white and pansy violet, $3 \mathrm{ft}$.

$2.50 \quad 20.00$

Seminole, violet rose, to crimson 30 in.

2.50

Violacea Grandiflora, violet blue, $3 \mathrm{ft}$.

.30

$3.00 \quad 20.00$

.50

5.00 Iris] mixed colors

3.50

27.50

.30

$3.00 \quad 20.00$

.30

$3.00 \quad 20.00$

.30

$3.00 \quad 20.00$

.25

$2.50 \quad 15.00$

3 feet.

LATHYRUS latifolius [Perennial $P i n k]$ Beauty, deep rose.

.50

$5.00 \quad 37.50$

.30

$3.00 \quad 20.00$

18 inches

.35

$3.50 \quad 27.50$ Star or Gay Feather] purple, $3 \mathrm{ft}$

LINUM perenne [Perennial Flax] pale blue, $2 \mathrm{ft}$.

$2.50 \quad 20.00$

.20

$2.00 \quad 15.00$ Pink] cardinal, $2 \mathrm{ft}$.

$2.00 \quad 15.00$

$3.50 \quad 27.50$

.20

$2.00 \quad 15.00$

.40

$4.00 \quad 30.00$

.35 
LILLIUM - continued

Each Per 12 Per 100

- regale [The Regal Lily] white, suffused with pink,

$\begin{array}{lll}.75 & 7.50 & 55.00\end{array}$

- speciosum album [Speciosum Lily] white. .50

- magnificum [Great Speciosum Lily] rich deep red...

- - rubrum .50 5.00

LUPINUS polyphyllus albus [ Hardy Lupin] white, $3 \mathrm{ft}$.

- - roseus [ Hardy Lupin] shaded rose, $3 \mathrm{ft}$.

- - blue [ Hardy Lupin] light blue $3 \mathrm{ft}$.

$3.00 \quad 20.00$

MERTENSIA virginica [Bluebells] light blue, $1 \mathrm{ft}$.

MONARDA didyma [Oswego Beebalm] crimson-scarlet, $2 \frac{1}{2} \mathrm{ft}$..

OENOTHERA fraseri [Evening Primrose] pale yellow, $1 \mathrm{ft}$..

* - macrocarpa [Ozark Sundrops] yellow, 10 in.

- youngi [Youngs Sundrops] lemonyellow, $2 \mathrm{ft}$...

\section{PACHYSANDRA terminalis}

[Japanese Spurge]..

PAEONIA [Peony] Horticultural varieties as follows:

-Baroness Schroeder, flesh tinted to white, very large.

$1.00 \quad 10.00$

Clair Dubois, deep rose, tinted silver.

1.50

Delachi, late red..

Edulis superba, deep pink, early large.

Felix Crousse, a standard red.

$.75 \quad 7.50$

Festiva Maxima, large white, very fine..

General MacMahon, red.

Grandiflora, light pink, late.

1.00

Grover Cleveland, dark red.

1.50

Karl Rosenfeld, rich blood red........

La Perle, blush pink to white.

2.00

Livingstone, soft rosy pink, large...

1.50

1.00

Mme. de Verneville, early white....

Mme. Jules Elie, silvery lilac-rose, large.

Meissonier, brilliant crimson.............

- rubra, early red.

$.75 \quad 7.50$

President Taft, delicate pink, striped..

Sarah Bernhardt, apple-blossom pink, tipped, with silver.

Therese, delicate satiny pink

PAPAVER orientale [Oriental Poppy] scarlet. 
PAPAVER - continued

- Mrs. Perry, orange apricot, very fine.

PENNISETUM japonicum [Fountain Grass] mahogany..

PENSTEMON barbatus torreyi [Beard Tongue] scarlet, $3 \mathrm{ft}$.

*PHLOX amoena [Amoena Phlox] bright pink, 4 in.

-Athis, deep clear salmon..

Beacon, brilliant cherry-red

*divaricata canadensis, lavender, 10 inches.

Elizabeth Campbell, bright salmon-pink.

Ferdinand Cortez, purplish red......

Henry Murger.

Miss Lingard, large tall white, elegant

Mrs. Jenkins, white ,large.

Prof. Virchow, bright carmine

Rheinlander, immense salmon pink

Rijnstroom, rose-pink

Sir Edwin Landseer.

*subulata alba [Moss Pink] white, 4 in

* - lilacina, light lilac, 4 in.

*- rosea, rose-pink, 4 in.

* - vivid, bright fiery rose

PHYSALIS franchetti [Chinese Lantern Plant] orange fruits, $2 \mathrm{ft}$..

PHYSOSTEGIA virginica [False Dragonhead] pink, $3 \mathrm{ft}$

- vivid, deep pink, $3 \mathrm{ft}$.

PLATYCODON grandiflora [Balloonflower] blue, 18 in.

*PLUMBAGO larpentae [Leadwort] deep blue, 8 in..

POLEMONIUM richardsoni [ $\mathrm{Cacob}$ 's Ladder] sky-blue, $1 \mathrm{ft}$.

*PRIMULA veris [ Hardy Primrose] mixed color, 6 to 9 in.

PYRETHRUM roseum [Painted Daisy] deep red, rose \& white, $2 \mathrm{ft}$

*RANUNCULUS repens flore plena [Buttercup] deep yellow, 18 in.........

RUDBECKIA lacinata fl. pl. [Golden Glow] yellow, $5 \mathrm{ft}$.

- newmanii [Showy Coneflower] deep orange, $3 \mathrm{ft}$.

- purpurea [Purple Coneflower] reddish purple, $3 \mathrm{ft}$.

SALVIA azurea [Azure Sage] skyblue, 3 to $4 \mathrm{ft}$.

- farinacea [Mealycup Sage] pale blue, $2 \mathrm{ft}$.

- pitcheri [Large Meadow Sage] gentian-blue, 3 to $4 \mathrm{ft}$.

*SAPONARIA ocymoides splendens [Soapwort] rosy-pink, 6 in..

Each Per 12 Per 100

.50

5.00

$.35 \quad 3.50$

.25

2.50

.30

$3.00 \quad 20.00$

$\begin{array}{lll}.35 & 3.50 & 27.50\end{array}$

$\begin{array}{lll}.35 & 3.50 & 27.50\end{array}$

.30

$3.00 \quad 20.00$

.35

3.50

$.35 \quad 3.50$

.35

$3.50 \quad 27.50$

.35

$3.50 \quad 27.50$

$\begin{array}{lll}.35 & 3.50 & 27.50\end{array}$

$\begin{array}{lll}.35 & 3.50 & 27.50\end{array}$

$\begin{array}{lll}.35 & 3.50 & 27.50\end{array}$

$\begin{array}{lll}.35 & 3.50 & 27.50\end{array}$

$\begin{array}{lll}.35 & 3.50 & 27.50\end{array}$

.30

$3.00 \quad 20.00$

$\begin{array}{lll}.30 & 3.00 & 20.00\end{array}$

$\begin{array}{lll}.30 & 3.00 & 20.00\end{array}$

$\begin{array}{lll}.35 & 3.50 & 25.00\end{array}$

.20

$2.00 \quad 15.00$

.20

$2.00 \quad 15.00$

$\begin{array}{lll}.30 & 3.00 & 20.00\end{array}$

.25

$2.50 \quad 17.50$

.25

$2.50 \quad 17.50$

.35

$3.50 \quad 27.50$

.35

$\begin{array}{ll}3.50 & 27.50\end{array}$

.30

$3.00 \quad 20.00$

.25

$2.50 \quad 17.50$

.20

$2.00 \quad 15.00$

.20

$2.00 \quad 15.00$

.20

$2.00 \quad 15.00$

.25

$2.00 \quad 17.50$

$2.00 \quad 17.50$

.35

$3.50 \quad 27.50$

.25

$2.50 \quad 17.50$ 
SCABIOSA caucasica [ $P$ in Cushion

Each Per 12 Per 100

Flower] lavender, 18 in

.30

$3.00 \quad 20.00$

SIDALCEA [ Prairiemallow] Rosy Gem, rose, $2 \mathrm{ft}$.

.30

$3.00 \quad 20.00$

SILPHIUM alpina subcoeruleus [Rosinweed]. .30

- perfoliatum [Cup Rosinweed] yellow, 6 to $8 \mathrm{ft}$..

.30

$3.00 \quad 20.00$

*SEDUM acre [Golden Moss, Stonecrop] yellow, 2 to 3 in.

$3.00 \quad 20.00$

* - album, white, 2 to 3 in.

$2.00 \div 12.00$

*- kamschaticum, [Orange Stonecrop] yellow, 8 in...................................... . .20

*_lydium [Lydian Stonecrop].............. . . .20

*_ reflexum [Jenny Stonecrop]............ . .20

* - sexangulare [Hexagon Stonecrop] yellow, 4 in.

$2.00 \quad 12.00$

$2.00 \quad 12.00$

$2.00 \quad 12.00$

$2.00 \cdot 12.00$

* - sieboldi [Siebold Stonecrop] blue foliage, pink, 9 in.

$5.00 \quad 37.50$

* spectabile [Showy Stonecrop] pink $1 \frac{1}{2} \mathrm{ft}$.................................... . . 30

*- stenopetalum................................. . . 20

$3.00 \quad 15.00$

$2.00 \quad 12.00$

*-stolonifera [Running Stonecrop] pink, 6 in.

*- - coccinea, crimson, 6 in.

$2.00 \div 12.00$

$2.00 \quad 12.00$

*SEMPERVIVUM [ Houseleek] in variety, 2 to 6 in....

$2.50 \quad 15.00$

SPIRAEA davidi, large plumes of violet flowers, $5 \mathrm{ft}$........................... . .50

* - filipendula [Dropwort] white, 15 in. .35

— Gruno................................................. . . .50

— Juno ............................................ . .50

- palmata elegans, light pink, $3 \mathrm{ft} . . \quad .50$

— Pink Pearl, delicate pink, $3 \mathrm{ft}$......... $\quad .50$

— rosea, pink ……………………….... $\quad .50$

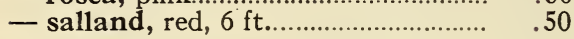

- ulmaria fl. pl., [Meadow Sweet] creamy white..................................... . .35

— Vesta, lilac rose.................................... . . .50

— White Pearl, large white.................. $\quad .50$

*STACHYS betonica grandiflora [Betony] silvery foliage, 4 in.......... .35

$5.00 \quad 37.50$

$3.50 \quad 27.50$

5.00

5.00

5.00

5.00

5.00

5.00

$35 \quad 3.50$

$3.50 \quad 27.50$

5.00

5.00

35

$3.50 \quad 27.50$

*STATICE latifolia, [Great SeaLavender] purplish blue, $2 \mathrm{ft}$..

$3.00 \quad 20.00$

STOKESIA cyanea coerulea [Cornflower Aster] sky-blue, $2 \mathrm{ft}$...

THALICTRUM aquilegifolium [Meadow Rue] pure white, $2 \mathrm{ft}$....... .50

5.00

- dipterocarpum, rosy purple, $4 \mathrm{ft}$.. $\quad .50$

5.00

THERMOPSIS caroliniana [False Lupin] yellow, $3 \mathrm{ft}$.

*THYMUS citriodorus aurea [Thyme] golden yellow, 4 in........... . 20

$2.00 \quad 15.00$

$\begin{array}{lll}.20 & 2.00 & 15.00\end{array}$

$.20 \quad 2.00 \quad 15.00$

* - serpyllum, white, 4 in.

$3.50 \quad 27.50$ wort] blue, $2 \mathrm{ft}$. 
Each Per 12 Per 100

TROLLIUS europaeus [European Globe

Flower] lemon, $2 \mathrm{ft}$.

$.40 \quad 4.00$

*TUNICA saxifraga [Tunicflower]

light pink, 6 in.

$.20 \quad 2.00 \quad 15.00$

VALERIANA coccinea [ Hardy Heliotrope] light-pink, $4 \mathrm{ft}$.

$.20 \quad 2.00$

*VERONICA incana [Speedwell] blue, $1 \mathrm{ft}$.

- longifolia subsessiles [Clump Speedrvell] blue, $2 \mathrm{ft}$.

* - repens [Creeping Speedwell] light blue, 4 in.

*- rupestris [Rock Speedwell] bright blue, 3 in.

spicata rosea [Spike Speedwell] pink 2 feet.

$\begin{array}{lll}20 & 2.00 & 15.00\end{array}$

*VINCA minor [Periwinkle] trailing green foliage, shade.

YUCCA filamentosa [ $A$ dam's

Needle] tropical appearance, white, 4 feet.

\section{THE FRUITS}

All of our fruit trees are carefully grown, true to name, healthy and well formed. They are graded according to the Horticultural Standards of the American Association of Nurserymen. The caliper is taken two inches above the bud. Unless specially mentioned the apple, cherry, plum, pear and quince trees are two years old and the peach trees are one year old.

\section{APPLES \\ Standard and Crabs \\ Each Per 10 Per 100

$\begin{array}{lrr}.85 & 7.50 & 55.00\end{array}$

$\frac{11}{16}$ inch and up, 4 to 6 feet

\section{Standard Varieties:}

Summer Fruiting: Duchess [greenish yellow, red stripe]; Earley Harvest [yellow]; Red Astrachan [red, striped]; Yellow Transparent [yellow].

Fall Fruiting: Maiden Blush [yellow with blush]; Rambo [dull yellowish-red]; Wealthy [bright red, striped];

\section{Winter Fruiting:}

Baldwin [deep red]; Banana [golden yellow]; Delicious [red]; Greening [green]; Grimes Golden [yellow]; Jonathan [bright red]; Northern Spy [red, striped]; Rome Beauty [red]; Stark [yellowish green]; Stayman [dull red]; Talman Sweet [yellow]; Winesap [red].

Crab Varieties:

Hyslop [yellow, shaded deep crimson]; Transcendent [brownish-yellow]; Whitney [yellow, red striped].

\section{PEACHES}

\section{$\frac{9}{16}$ inch and up, 4 to 5 feet......... $\quad .75 \quad 6.50 \quad 55.00$} Varieties:

Early Ripening: Admiral Dewey [yellow, freestone] Belle of Georgia [white, freestone]; Carmen [white, freestone]; Greensboro [white, semi-cling].

Mid-season Ripening: Crosby [yellow, freestone]; Champion [white, freestone]; Elberta [yellow, freestone]; Fitzgerald [yellow, freestone]; J. H. Hale [yellow, freestone]; Mountain Rose [white, freestone].

Late Ripening: Old Mixon Free [white, freestone]; Heath Cling [white, cling]; Smock [yellow, freestone]; Salway [yellow, freestone]; Stump [white, freestone]. 


\section{CHERRIES}

Each Per 10 Per 100

$\frac{11}{16}$ inch and up, 4 to 5 feet.... $1.50 \quad 12.50 \quad 100.00$ Varieties:

Black Tartarian [sweet]; Early Richmond [sour]; Governor Wood [sweet]; Montmorency [sour]; Windsor [sweet].

\section{PEARS}

$\frac{11}{16}$ inch and up, 4 to 5 feet.... $1.50 \quad 12.50 \quad 100.00$ Varieties:

Bartlett; Clapps Favorite; Duchess; Flemish Beauty; Kiefer; Seckel; Sheldon.

PLUMS

\section{Varieties:}

Abundance [red]; Bradshaw [very large, violet-red]; Burbank [red]; Lombard [violet red]; Moore's Arctic [dark purple]; Reine Claude [green]; Shippers Pride [dark purple]; Shropshire Damson [blue].

\section{QUINGES}

$\frac{5}{8}$ inch and up, 3 to 4 feet........... $1.25 \quad 10.00 \quad 90.00$ Varieties: Orange and Champion, both ripening in October. :

\section{APRICOTS}

4 to 5 feet.

$$
1.25 \quad 10.00
$$

3 to 4 feet

\section{PERSIMMONS}

$$
1.50 \quad 12.50
$$

\section{GRAPES}

Concord $\begin{array}{lll}.25 & 2.00 & 17.50\end{array}$

All other Varieties.

$\begin{array}{lll}.35 & 3.00 & 25.00\end{array}$

Varieties: Agawam [large red]; Brighton [red]; Catawba [large red]; Concord [the standard blue]; Delaware [small red]; Moore's Diamond [white]; Moore's Early [large black]; Niagara [the standard white]; Woodruff [large red]; Worden [a good blue].

\section{RASPBERRIES}

Columbian [purple] Per 10 Per 100 Per 1000

Cumberland [black] $\begin{array}{lll}1.00 & 7.50 & 45.00\end{array}$

King [best red] $\begin{array}{lll}.75 & 5.00 & 35.00\end{array}$

$\begin{array}{llll}1.00 & 7.50 & 40.00\end{array}$

St. Regis [ever-bearing red] $\ldots \ldots \ldots . . .1 .00 \quad 7.50 \quad 50.00$

BLACKBERRIES

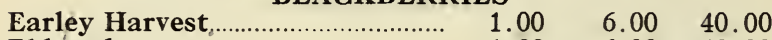

Eldorado ............................................ $1.00 \quad 6.00 \quad 40.00$

\section{GOOSEBERRIES}

Each Per 10 Per 100

Two year old plants...................... $.35 \quad 3.00 \quad 25.00$

Varieties: Downing, Houghton, and Red Jacket.

\section{GURRANTS}

$\begin{array}{lllll}\text { Two year old plants....................... } & .35 & 3.00 & 25.00\end{array}$

Varieties: Cherry, Fays Prolific, Red Dutch, White Grape.

NOTE-Gooseberries and Currants must not be shipped west of the Mississippi River.

\section{STRAWBERRIES}

Per 10 Per 100 Per 1000 [sold in spring only]

Spring Bearing Sorts................... $.50 \quad 1.50 \quad 9.00$ Varieties: Senator Dunlap, Gandy, and Haverland.

$\begin{array}{llll}\text { Everbearing Sorts ........................... } & .75 & 2.50 & 12.50\end{array}$

\begin{tabular}{|c|c|c|c|c|}
\hline Palmeto [green]. & ASPARAGUS & .75 & 3.00 & 15.00 \\
\hline & RHUBARB & & & \\
\hline naeus... & 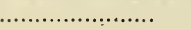 & .25 & 2.00 & 15.00 \\
\hline
\end{tabular}

Varieties: Progress and Superb. 


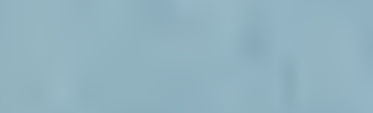

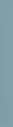

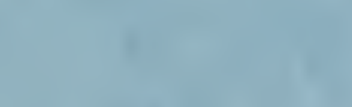

$=0$

(n)

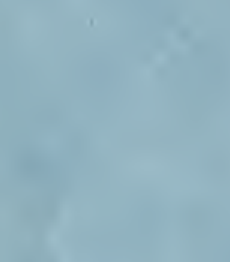<smiles>CCC</smiles>

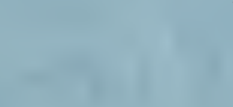

(n)

\section{1}

(1) 


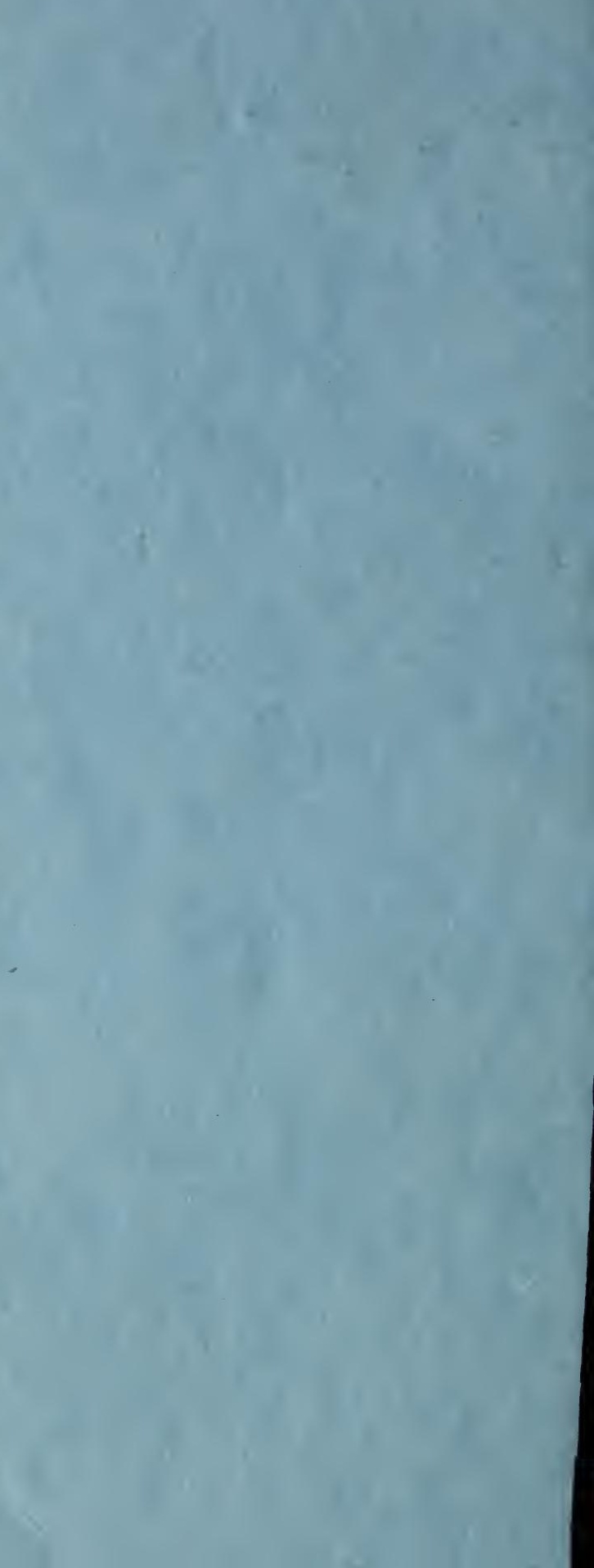

